PART ONE

Norms

Stem Structures and Practices 



\title{
The Language and Contours of Familial Obligation in Fifteenth- and Sixteenth-Century Japan
}

\author{
David Spafford
}

\begin{abstract}
Forgetting the repeated grace of your lord and father is a lapse in loyalty and filial piety

- IMAGAWA PRECEPTS (EARLY FIFTEENTH CENTURY)
\end{abstract}

By the fourteenth century, the house (ie) had emerged throughout Japan as the fundamental unit of kinship among warrior elites; in its mature form it would endure, without major structural evolution, until the abolition of the warrior class in the late nineteenth century. Rather than surveying the entire arc of the warrior house's existence, I focus here on the fifteenth and sixteenth centuries, when the survival of individual houses was threatened most acutely by ongoing countrywide strife and when daily concern with violence inspired a raft of documents on the values that might hold members together. Over nearly 150 years, in law codes and collections of moral precepts but also in private missives and political negotiations, warriors again and again reflect upon family relations, both in idealized abstractions and the contingent cases of their own houses.

In the following pages, I explore these documents and the ways they frame a preoccupation with what I call the contours of familial obligation. I expose, in particular, how a native vocabulary of service is overlaid with a Chinese vocabulary of loyalty and filial piety, the demands of which served to bind increasingly distant and potentially estranged relatives as well as increasingly long serving nonkin affiliates (housemen). Crucial to this integration, I argue, is the dominance of the language of loyalty (theoretically directed at nonkin) over the language of piety (directed at kin) and the recurrent fusion of kin and nonkin under the rubric of loyalty. The blurring of distinctions enhanced the cohesiveness of a group in which membership was potentially elective by taking advantage of the essential 
homology, in the ethical framework borrowed from the continent, between the lord-subject and father-son relations.

\section{THE CORPORATE HOUSE'S AFFILIATES}

As an institution, the warrior house was several things at once, but its core function was managing property rights and the access of members to offices. To a one-time observer, a house would look like a stem family composed of three generations: a house head and his wife, the couple's (sometimes adopted) son and successor, and the head's parents. Yet to those within it, invested in the perpetuation of ancestral status and wealth, the house was always conceived in terms of its history, as a lineage stretching back in time to its founder. Over the generations, membership expanded and contracted and grew ambiguous along the edges.

A house encompassed both dependent kin and variously affiliated nonkin. Noninheriting relatives-primarily the current head's unmarried daughters and nonsucceeding sons, and secondarily his siblings, aunts and uncles, and their offspring-sometimes remained part of the house and often played significant roles despite their exclusion from the main line of succession. But brothers' sons were cousins; cousins' sons were second cousins; and so on. How distant must a relative become before he was no longer viewed as a member of the house? When needed, the proliferation of dependent kin was controlled by allowing noninheriting males to found their own separate houses. These were patrimonially independent but closely allied to the founders' natal houses (at least before time loosened the ties of kinship). More distant relations often remained, in fact if not in theory, members of the house. These included the descendants of nonsucceeding sons of previous heads as well as the maternal relatives of current or past heads, many of whom left their natal houses and threw in their lot with in-laws.

The marginalization of daughters and nonsucceeding sons marked the house as much as the (loose) inclusion of more distant kin, underscoring how the institution took shape in response to twin warrior concerns: on the one hand, with the fragmentation of wealth and prestige over time; on the other hand, with the maximization of military resources (and personnel) in times of turmoil. Sons and daughters, who in the twelfth and thirteenth centuries had been entitled to a share of their parents' assets, saw their claims sacrificed to the imperative of house survival, as the development of the role of designated successor (not necessarily the firstborn) led to the eclipse of partible inheritance. ${ }^{1}$ Indeed, the designated son's monopoly on resources completed not only the house's patriarchal transformation but also, in a sense, its reification as an institution. As it emerged by the fourteenth century, the house transcended contingent configurations by linking the family name with a body of "ancestral" holdings that, handed down from generation to generation, signified its identity and continuity. ${ }^{2}$ 
The house had not always been the prevalent model of familial organization. Before the appearance of warriors as political actors in the twelfth century, extended kinship groups known as uji (sometimes translated as "clans") had dominated the political scene at the imperial court in Kyoto. Members of uji practiced uxorilocal marriage and selected as heads those members who held the highest ranks and offices at court, thus relying neither on primogeniture nor on lineal succession. Warriors did not, for the most part, start out as members of the tightly knit Kyoto aristocracy, nor were they as invested in the shared system of honors and rewards that defined it. As their involvement in political struggles grew, they did begin to compete for the prestige (and in some cases the authority) conferred by courtly titles. But this competition did not take place within the extended kinship group of the clan, as it did for courtiers, or give shape to its succession crises. Rather, much like land and followers, ranks and offices became assets to be transmitted lineally, from generation to generation. Because eligibility for public office was a resource assigned through the framework of the house, membership became the primary determinant of a man's standing in local society. The house, then, did more than structure kinship; in an increasingly fragmented and unsettled society, it also organized political life. Indeed, in its fullest definition, the house should be understood as functioning as a corporate rather than simply a kinship group.

This corporate group included nonkin as constituent, necessary members. Men (and, indirectly, women) who shared neither a surname nor an ancestor with the house head or his successor played vital roles in managing a house's assets and fighting its battles. More even than distant relatives, these nonkin affiliates expose the porousness of the boundary between the familial and the political. The subordinate affiliation of these nonkin followers was voluntary, subject to negotiation and renegotiation as circumstances and opportunities dictated. Yet, at their most successful, these ties of patronage and service could be long lasting, spanning multiple generations. Unlike the ties that bound kin, which weakened inexorably over time, the bonds of service between lords (heads of a house) and housemen were believed to grow stronger with every new generation. And while such beliefs often clashed with realities, long track records of unflagging and distinguished support did allow nonkin to rise to positions of leadership within a house. Some secured for themselves and their descendants titles such as elder or majordomo that gave them an important say in matters of policy and succession. Men like Asakura Takakage (1428-81) and Nagao Tamekage (1489?-1543) are now notorious for betraying their lords and taking their places, but both began their careers (and had the chance to mount their rebellions) because of the influence they wielded within the houses they served.

So, what was a houseman? The term is an ambiguous one that translates equally ambiguous Japanese terms (such as kashin or kerai), which denote anyone in the service of a house. And, in practice, housemen refers to a great range of subordinates. Some were petty warriors who resided near or with the house 
they served and enjoyed very little autonomy. Others had greater landed wealth and followings of their own and might oscillate, as political and military circumstances dictated, between unequal alliances and fully fledged submission. The more autonomous among them could and would negotiate the terms of their service, though appointment to offices within the house's administrative apparatus was as sure a sign as any that bonds were long lasting and commitment to the house was strong.

Still, being or not being part of a house could be a matter of perspective. Turning neighboring warriors into housemen (Japanese scholars refer to the process as vassalization) was a long-term proposition and even the greatest families often struggled to forge reliable ties with would-be followers. ${ }^{3}$ Beginning in the latter half of the fourteenth century, those who held offices in the central regime's provincial administration, such as military governors, appointed trustworthy followers as deputies, using official posts to bolster private alliances. Governors also exploited their powers of requisition to commandeer revenues (and, eventually, actual plots of land) from local estates, which they then distributed among their worthier followers. These acts carried the validation of public authority. At the same time, such rewards exposed the authority of the state as contiguous to, and barely more awesome than, that of the house. They bought the services of local warrior houses but highlighted the negotiable character of allegiance. In the end, for many great houses that held official appointments in the provinces, the failure to make local warriors into fully fledged housemen-the failure to transform a jurisdiction into a house-would spell doom.

In practice, the very distinction between what was state sanctioned and public and what was house based and private seems to have been largely rhetorical. The conflation, in the service of the house, of public resources with private ends was not occasional or accidental; the ambiguous boundaries between these spheres were essential to the house's function as the center of warrior networks of sociability and power. Indeed, as a model for relations based on service, the corporate house was so versatile that it operated in much the same fashion at all levels of warrior society. Despite differences of scale, houses that controlled entire provinces and thousands of warriors negotiated relations with kin and nonkin affiliates in ways perfectly intelligible to houses with few holdings and mere dozens of members. However rickety in times of crisis, the pyramidal structure of houses, which made the heads of lesser houses into the housemen of more powerful houses (the "great names," or daimyo, of the age), coincided with the country's political hierarchy: the house of the shogun, who rested his authority to rule on a mandate from the imperial court, stood at the pinnacle of warrior society as the "Buke," the Warrior House.

The corporate character of the house, then, was at once its critical attribute and its critical operational challenge. Given the centrality of the house to warrior society, its elastic and composite character, and the ambiguity of resulting relations, 
it is no surprise that the ie became the object of pervasive rhetorical scrutiny in times of civil unrest.

\section{THE CALCULUS OF SERVICE AND REWARD}

By the fifteenth century, we find countless missives, composed on the eve of campaigns or in the wake of battles, dotted with references to loyalty and loyal service. Most often authored by great lords in times of need, these letters reflected neither academic philosophy nor ruminative indulgences; they combine congratulations for service rendered with exhortations to future deeds. And they tend, throughout, toward formulaic turns of phrase. In 1473, for example, the shogunal deputy Hosokawa Katsumoto urged a local warrior to "serve loyally" in exchange for confirmation of rights to various parcels of land. ${ }^{4}$ Ashikaga Shigeuji, a relative and rival of the shogun, praised two of his partisans, sixteen years apart (in 1451 and 1471), in nearly identical language: their loyalty was "[truly] incomparable, the height of service." In 1506, Shigeuji's son and heir lauded a follower's "unique loyalty." ${ }^{\text {Local }}$ lords were no less grandiose in their effusions: Utsunomiya Shigetsuna praised a follower's "incomparable loyalty" in 1495, adding that "he rejoiced at [the man's] repeated [demonstrations of] loyalty."

Two observations arise from this handful of examples. First, service was the fundamental currency of political and military transaction. It governed all acts of political affiliation and partisanship. The actions of a houseman fighting on behalf of his lord's house and those of a local warrior answering the muster of a shogunal official deserved the same sort of praise because they were not conceptually (or morally) distinct. And regardless of actual sentiment, both were carried out for reward and then cloaked in the guise of personal fidelity.

Second, these documents are not only formulaic but hyperbolic. Lavish effusions were evidently as expected as familiar turns of phrase and were possibly more necessary. The effusions compel us to recognize that the ties binding nonretainers to a house, however crucial to advancement, were both theoretically and practically voluntary. ${ }^{8}$ The very real possibility that service might not be performed in moments of need, or that rewards might not be forthcoming afterward, is implicit in the trove of synonyms that developed to describe lords' and followers' respective obligations and to extol their proper fulfillment. Indeed, the rote formulas privileged in this sort of document may well have served to reassure parties that the terms of the contract would be fulfilled without deviating from stipulations. All meaningful action was service, and all service was negotiated.

Yet the mechanics of the transactions were not laid bare. A subordinate's search for the most advantageous deal stood in perpetual tension with a lord's need for reliable supporters. Hence, the marketplace logic of negotiable service had to be downplayed in lords' pronouncements: service was always and emphatically loyal service. The most striking assertion of this association is in a letter to a follower 
written in 1489 by Uesugi Sadamasa: "Loyalty is service." 9 In offering what amounts to a definition of loyalty, Sadamasa's statement alerts us to the way in which such an ideal suffuses the rich and ubiquitous vocabulary of service. If, indeed, loyalty is service, we must consider service as both a form of social and political affiliation and an expression of morally virtuous conduct. References to service become references to loyalty.

The tension between loyalty and contract, willfully suppressed in brief letters of congratulation, is evident in more extensive documents where rote but flamboyant praise gives way to greater nuance. In Hobby Horse Notes (Chikubashō), a collection of precepts composed in 1383 by shogunal deputy Shiba Yoshimasa, a criticism is leveled at fellow warriors: "As for serving one's lord, everyone believes he must receive favor before offering loyalty and service." ${ }^{10}$ Yoshimasa, one of the most powerful figures of his day, wrote at a time of relatively strong central authority when the balance of power between lords and followers tipped decidedly toward the former. Yet even he was forced to recognize how seldom so-called loyalty and service were offered without up-front payment. The burden of initiative, he seems to tell us, was on would-be recipients of service.

A mid-sixteenth-century author accustomed to decades of civil war and volatile alliances was less critical, if no less explicit, about the negotiated character of loyalty and service. In the Recorded Sayings of Asakura Sōteki, a collection of reflections on rulership and political strategy, the phrase "serving loyally" recurs over and over as if all service must be a matter of loyalty. Yet the contractual nature of the ties that bound lords and followers is also explicit: "Since [various petty warriors] have been granted [fiefs] so widely, all feel grateful and serve loyally, and consequently until now our province has long been ever more prosperous." Here, Sōteki echoes Yoshimasa in suggesting that rewards for service were, in fact, advance payments. Perhaps because Sōteki was not the head of the Asakura house but an advisor to its leadership, he is also attentive to the daimyo's obligations to his followers: "In particular, it goes without saying for those who have served for a long time, but even for those who have newly joined our side, that after a life of loyal service if they have young children, you must act considerately and treat them with the greatest care, so that they grow up [and prosper]."12 In this formulation, the moral power of "loyal service" constrains lords and followers alike.

In declaring that "loyalty is service," Uesugi Sadamasa seems to have been intent on giving a practical dimension to a crucial virtue. Yet if loyalty was in need of definition, service itself did not seem to require much explanation at all, at least if we judge from extant statements. In the Recorded Sayings of Asakura Sōteki we find references to simply "being personally in attendance" and "being of great use." ${ }^{13}$ In other fifteenth- and sixteenth-century texts, warriors write of "being in attendance" or of "serving their lord." ${ }^{4}$ Somewhat less opaquely, they boast of many years of "military service," using a term (gun'yaku) that equates service with an actual levy of sorts. ${ }^{15}$ To be sure, both in articles of law and in moral 
injunctions the Japanese expressions are more varied than the English translations. My monotonous use of the rubric of service may lend to the actions in question greater semantic homogeneity (and conceptual consistency) than they had; it likely also makes them out to be more abstract than they were conceived. In their variety, the original utterances suggest an understanding of service that was not driven by a formal and unitary set of rules but, rather, assembled through custom out of an array of discrete actions and interactions. Even in normative statements like Sadamasa's, service and loyalty were loose categories of conduct that emerged organically and dialectically from the process of warrior society formation.

And here lies the key: what was invoked most urgently was not the ideal ("loyalty") but the actual conduct and duty that embodied it ("loyal service"). And as something one did, serving loyally could be quantified and verified and-when successful warlords began to regulate their authority in writing-legislated. In practice, loyal service meant providing troops when requested. Records of mobilizations from the fifteenth and early sixteenth centuries, relatively scarce and laconic, do not lend themselves to quantitative assessments of the quid pro quo that enabled ongoing relationships. We must deduce patterns from the rare references to individual negotiations during campaigns (such as one that took place in the early 1470 s between the Iwamatsu and the Uesugi). ${ }^{16}$ But by the mid-sixteenth century, daimyo did begin systematizing their demands, exacting set troop mobilizations from subordinates on the basis of the value of the lands granted to them. ${ }^{17}$ Another measure of loyal service, particularly when warriors with little leverage answered the summons of provincial authorities, was distinction on the battlefield, which authorized claims to rewards. In 1473 Shogun Ashikaga Yoshimasa sent nearly identical letters of commendation to various lords fighting in his army: "Several among your vassals either perished or suffered wounds; this is most splendid. . . . I am most moved by your loyal success." ${ }^{18}$ Killing enemies or sustaining casualties represented convenient metrics for performance. That both inflicting and sustaining damage could be considered as measures of merit points yet again to the moral dimension of service. Loyalty measured effort and sacrifice.

The legal codes issued by daimyo, which appear rather suddenly from the 1520s, offer no systematic reassessment of the compacts between houses and their affiliates, but they do help us gauge the concrete ramifications of the vague invocation of "loyal service." ${ }^{19}$ Article 10 in the 1553 supplement to the Imagawa house code, for instance, is entirely devoted to how the manifestations of the daimyo's favor (the lands bestowed as rewards for meritorious conduct) may be handed down to descendants. ${ }^{20}$ Because service generated rewards that were then bequeathed to sons and grandsons, the transferred lands were visible and quantifiable bonds. They created expectations of continuing relationships between lineages. In this regard, a daimyo's "favor" tethered his house to his followers' houses as surely as it cast the relationship in unmistakably hierarchical terms. But those terms were also conditional. The choice of euphemism matters: implicit in the choice of the 
word favor (rather than the more explicit land) is the sense that continued tenure depended on continued goodwill.

Another sixteenth-century code, issued by the Chōsogabe house in 1596, is more explicit in casting service and favor as foundations for bonds expected to last generations-relationships between houses rather than individuals. Article 84 states: "In the matter of succession to a loyal family: When the heir's service has been lacking and a punishment is in order, if his failings have been light the penalty should not attach to the family name; if they have been serious, the penalty must attach to the family name."21 Here, the authority of the lord's house extends not only to individual nonkin affiliates but considers followers' entire households as nested within the lordly house and regulates their succession-that most crucial and perilous of processes-in accordance with service rendered. Not individuals but families were the performers of loyal service; serious lapses by individual members were met with penalties that affected an entire family's name.

The ostentatious appeals to morality, then, served to ennoble a relationship that was contractual; they established a protocol of sorts that made more palatable the conditional nature of both service and favor to lords and followers alike. The moral nature of the compact, in turn, allowed lords to remind followers, and those followers' descendants, of their ongoing obligations by offering them the opportunity to renew the original virtuous commitment. But such reminders signal the effort through which lords cultivated other houses' ongoing affiliation and submissionan inherently unstable relationship made all the more unstable by the dangers and opportunities of civil war. If loyalty could be used to cloak the contractual nature of such relationships, further articulation of the concept was necessary to ensure their stability.

\section{LOYALTY AND PIETY IN THE MAKING OF THE VIRTUOUS HOUSE}

One crucial way of stabilizing relations between houses and their supporters was to recast provisional, negotiated alliances as exchanges of virtue-to obscure, in effect, the quasi-egalitarian and contingent dimensions of contractual agreements by representing them as moral agreements in accord with unchanging ideals of conduct. Daimyo did not have to search far for a useful moral vocabulary. The Confucian moral order, with its emphasis on archetypical social relations, each governed by appropriate behavior, had been known in Japan for centuries. Most apposite among the virtues advocated by Confucianism was loyalty, which was not simply the obedience a follower owed to his master (since a good subject was expected, for example, to remonstrate with a master who strayed) but an ideal of moral conduct that could elevate "loyal service" to a form of exemplary human fulfillment (not least because the words for "loyalty" and "loyal service" were cognates). 
Would-be moralizers in Japan used the Chinese template in a variety of ways, often simultaneously. They drew on the connotations of the continental virtue when they claimed, implicitly or explicitly, that loyalty and service were one and the same. They also leaned on Chinese textual authority to lend force to their own maxims (a practice used as early as the seventh century in Prince Shōtoku's "Seventeen-Article Constitution"). Thus, for example, each of the injunctions in the code of Takeda Nobushige (1525-61) backs up advice with quotes from canonical or semicanonical continental texts: "Never forget loyal vassals. Three Strategies says, 'If good and evil are treated as the same, skilled vassals will be at a loss."'22 Only a few decades later, Tokugawa Ieyasu would use a similar combination of pragmatic instructions and (sometimes ill-fitting) continental references in his 1615 code for daimyo, the "Laws Governing the Military Houses" (Buke shohatto).

Yet examples like Nobushige's, I would submit, illuminate a more crucial valence of the borrowing process: references to Confucian loyalty immerse statements about a follower's obligations to a house in a broader discourse about a society's foundational relationships. Invoking one relationship, with the behavior appropriate to it, meant invoking the Confucian system as a whole. Extolling the loyal subject, for instance, inevitably implied embracing other, "parallel" paragons of virtue, such as the pious son. Uesugi Sadamasa (quoted above) uses textual authorities to criticize his son and heir for his lack of virtue: "Even if he should read the Analects and the Classic of Filial Piety, we would see he has no filial piety and righteousness at all." ${ }^{23}$ A mid-sixteenth-century chronicle comments on the conduct of a Japanese warlord by quoting the Analects: "In that other country [China] it is said that if, in mourning a parent, one does not stray from one's father's path for three years, then one is filial." ${ }^{24}$

Indeed, the influence of continental texts is meaningful less in the direct borrowing of vocabulary or the citing of authorities than in the underscoring of associations between different categories of conduct. Stepping beyond filial piety's nominally familial ambit, Sadamasa's letter invokes the same virtue as a political necessity-for a son to become an heir and thus the next head of a house. The slippage between virtues of a son and those of a subject was not unique to Japan. In China, piety and loyalty had long been understood as essentially homologous: the ideal of lord-vassal relations, which called for loyalty to one's master and benevolence toward one's follower, was viewed as the public extension of the private ideal of father-son relations, and vice versa. But it was the father-son relationship, demanding piety of the son just as the lord-vassal relationship demanded loyalty of the vassal, that was held to be foundational in writing about social relations. The Classic of Filial Piety, a quasi-canonical treatise thought to have been compiled around the turn of the fourth century BCE and widely circulated in Japan, states: "[Piety] commences with the service of parents; it proceeds to the service of the ruler; it is completed by the establishment of the character." ${ }^{25}$ Elaborating further on the relationship between piety and other virtues, the text claims: "As they serve 
their fathers, so they serve their mothers, and love them equally. As they serve their fathers, so they serve their rulers, and reverence them equally. Hence love is what is chiefly rendered to the mother, and reverence is what is chiefly rendered to the ruler, while both of these things are given to the father." ${ }^{26}$

In Japan, the homology of loyalty and filial piety figured early on in warrior discourse; it was well established by the time it appeared in the famous chapter of the fourteenth-century epic The Tale of the Heike, in which the virtuous son of a wayward political leader reprimands his father as a loyal subject would. Ubiquitous mention of loyalty and filial piety in medieval Japanese texts attests to the wide currency of continental ideas. But was the normative character of precepts about families analytically alive, malleable, or was it no more than an inert touchstone? In other words, were filial piety and loyalty (and other such ideals) drawn upon self-consciously and with specific goals in mind, or had they long since become little more than a set of ingrained moral reflexes, to be used not as starting points for speculation but as reliable support for the reiteration of urgently felt (if not freshly interrogated) needs? In China, the concepts of zhong and xiao acquired somewhat stable connotations of loyalty and filial piety in the second half of the first millennium BCE. ${ }^{27}$ In Japan, numerous commentaries on the Classic of Filial Piety were authored or copied between the late fifteenth and the late sixteenth centuries, yet judging from the similarity between statements found in the Classic of Filial Piety and in daimyo's writings, medieval Japanese had not come very far in developing the originals' premises. ${ }^{28}$ No doubt, cultural and linguistic translation contributed to simplification, though it is difficult to avoid the sense that statements such as those collected in the Classic of Filial Piety drew whatever power they had from their simplicity and seeming self-evidence. Repeated over and over, formulaically, they had become axiomatic.

Still, even formulas could be used as more than rhetorical flourishes. If daimyo did not create the homology, they nonetheless made aggressive use of it: in the service of their houses' prosperity, they conflated the loyalty demanded of nonkin followers and the filial piety expected of offspring. They did so most consequentially in the law codes they started issuing in the sixteenth century. These codes typically combined laws governing the daimyo's house and housemen (which drew at least in part from the long tradition of writing moral injunctions for heirs and followers) with laws governing the domain (which derived from the regulations issued in previous centuries by centrally appointed military governors). ${ }^{29}$ Self-consciously or not, the moral authority claimed by injunctions was borrowed in the definition of mandatory (rather than purely desirable) behaviors and punishable (rather than simply reprehensible) offenses. Such borrowing suggests that the link between loyalty and filial piety mattered beyond the confines of rhetoric. In their laws, daimyo underscored the link in two ways: through the textual proximity of those who must be loyal and those who must be filial, and-less often but more significantthrough shared rules for the two groups. 
The legal space shared by kin and nonkin in law after law is striking. ${ }^{30}$ In a joint oath sworn by Shimazu Tomohisa and four others in 1480, "those who have ties" to "this honorable house" are listed with "longtime friends" in more than one article: "Whether it is someone with ties to this honored house, or someone who has long been its friend, turning one's back on the governor's directives should come to cause disturbances throughout the country." The oath also invokes "someone in the family who is at odds with Takehisa, whether he is a father or a son or a brother or a close friend." ${ }^{11}$ A similar grouping is found in the Imagawa house code: "One must not go so far as to report on the good and bad of a generous lord, of a teacher or superior, of a father and mother." ${ }^{32}$ In the comprehensive code of laws issued by the Takeda house of Kai in 1547, an article addresses together the private oaths of "relatives, retainers, and others," claiming that what keeps kin and nonkin followers loyal is serving side by side, not oaths. ${ }^{33}$

Some codes go further, with regulations imposed at once on kin and nonkin. In the rules that Kuroda Josui laid down upon taking possession of Bizen province in 1587 , not only are kin and nonkin subject to the same strictures, but the language of vassal duty is applied to kin: "Those who turn their backs upon the head of the house or upon their parents shall be punished." 34 Although it may be an overstatement to claim that "turning one's back" specifically describes those who are disloyal (rather than those who are unfilial), there is no doubt that kin, here, are equated with nonkin as objects of legislation and penalty. Nor were the Takeda and Kuroda rules novel. In an oath recorded by Kikkawa Mototsune and eight other local warriors in 1512, the conduct and punishment of kin and nonkin are indistinguishable: "When kin or retainers or others in our warrior band flee, whether because they despise their lord or because they have received a punishment, there must be no leniency." ${ }^{35}$ Examples abound. ${ }^{36}$

More than the occasional grouping together of kin and nonkin, this conflation suggests that, as categories of membership in the house, the same rules applied to relatives and vassals. To be sure, outside the immediate household of the daimyo even relatives were often tied to the main house as retainers. Yet this association often went so far as to include sons. The link between filial piety and loyalty operated even in legal definitions and, indeed, these codes share the presumption that kin and nonkin were liable to behave (and misbehave) similarly. The shogunal deputy Hosokawa Masamoto may have put it most clearly in 1501, when he decreed: "In the case of a family without assets/titles, if someone must be put to death, as in other matters, do not speak of the distinctions between lieutenants, relatives, retainers, followers, even if there are some sorts of gradations; first [the situation] must be relayed [to the authorities] by means of a messenger and a verdict must be issued [on the basis] of the Great Law." ${ }^{37}$ Another document, a 1526 oath by a far less eminent warrior (one Nakajō Fujisuke), is similarly opposed to making distinctions between kin and nonkin before the law: "Whether for a lieutenant or a relative, if things come to a judgment, we 
must not go as far as to back them, but entrust [the matter] to a directive from the provincial [governor's] office." 38

That a "feudal" vocabulary of service and favor-benefice developed indigenously means that the overlay of the vocabulary of Chinese virtue was not only unnecessary but also a leap. It was made, with intention, to reconfigure the transactional nature of relations as moral. No doubt, the Chinese-Confucian template did not exhaust ways of expressing the idea of loyal service; the late sixteenth and early seventeenth centuries were a time of almost unprecedented searching for new, more advantageous articulations of the fundamental exchange at the heart of the ties that bound daimyo (and then hegemons) to their followers. The simple availability of Confucian morality, then, does not alone explain its centrality to discourse on "the family" in Japan. Although Confucian ideas provide a full range of familial relations, the authors of many of our texts did not feel the need to systematically address each of them. Rather, these hoary continental ideals of lord-vassal and father-son relations were harped upon over and over becausetogether-they did an excellent job of capturing the structure of the ie and its most vital preoccupations. The parallel between loyalty and filial piety serves well in a context in which relations with kin and nonkin could advantageously be treated as homologous.

Making the house head into both a father and a lord, the daimyo codes regularized the conduct of inheriting and noninheriting offspring by subjecting them to laws. They also elevated the investment of nonkin by intimating (truthfully or not) that they would be held in the same emotional regard as kin. At the same time, daimyo took advantage of the widespread familiarity and systematic character of Confucian moral norms to suggest that the ideals of conduct for offspring and affiliates could be applied to both more or less interchangeably. The resonances between filialness and loyalty amplified the normative power of each. In many respects, an undifferentiated house membership is an objective running through the entire body of daimyo legislation. If achieved, though, it could create as many practical problems for a house as it resolved.

\section{THE BOUNDARIES WITHIN AND BETWEEN HOUSES}

My survey of texts that intimate, if not continuity, at least contiguity between a house's blood-kin core and its variously affiliated followers, raises two interrelated considerations. The first is that the categories of kin and nonkin are broad simplifications. There are sons and parents, but also relatives and those "of the same name"; there are retainers and housemen and followers, as well as those who have been clients and lieutenants. And not all codes or oaths juxtapose the same group of kin with the same group of nonkin. Pairing relatives and followers or, say, sons and retainers, no doubt blurred different lines. Treating the various laws cited above as expressive of similar premises runs the risk of overshadowing the specific 
relations and the specific points each text was intent on making. Yet the admittedly imprecise equation of a broad variety of kin with an even broader variety of nonkin allows us to establish what we might think of as the conceptual and rhetorical contours, the outer limits, of the house as the organizational hub of warriors' social and political life.

The second consideration derives from the first. That the two broad groups are itemized in articles of law and oaths is undeniable evidence that the two groups were indeed distinct, and that the distinction was worth underlining even in documents mandating one rule for all. The rhetoric of analogy served to underscore the members' shared investment in the house in the face of ever-present evidence that hierarchical distinctions were also differences of belonging (and, more dangerously, of investment). Yet the rhetoric was not only rhetoric, and the repeated grouping of kin and nonkin forces us to think more subtly about the problem of a house's internal hierarchies and differences; the line dividing kin and nonkin, while ever visible (and often problematic), was far from straight (or sharp). For example, Mōri Motonari, who otherwise was wont to exploit the flexible boundaries of kinship to his advantage, wrote to his son about how he must not trust housemen but only relatives by blood and marriage. ${ }^{39}$ At first glance, Motonari's comment seems to run against the grain of prevailing statements of equal or at least comparable membership for kin and nonkin, intimating that such statements did not always translate into equal treatment or trust. But it is worth drawing attention to his unusual classificatory scheme: in-laws are kin, a characterization that in ignoring the contingent and arbitrary character of kinship by marriage yet again complicates clear-cut distinctions between kin and nonkin, turning a binary into a gradient in which different factors could determine one's position.

Systemically, the line setting apart kin and nonkin within the hierarchy of the house was tangled by marriage ties between lords and followers. But the vagaries of individual personalities and skills also conspired to complicate clear-cut distinctions. Nonkin chief retainers often wielded more influence than distant cousins who happened to share a surname with their lords. We see this in countless succession crises, when factions emerged to support vying pretenders; when marriage alliances and ties of patronage became essential to success; and when senior housemen played outsized roles in the eventual selection, forging compromises that averted dangerous rifts among the house's affiliates. A notable example is that of Ise Sōzui (1456-1519, better known as Hōjō Sōun), an important retainer of the Imagawa house whose sister became the wife of its head, Yoshitada. When Yoshitada died on the battlefield, it was Sōzui-both Yoshitada's houseman and brother-in-law-who protected the infant heir against a rival claimant and brokered his succession. In the end, Sōzui emerged triumphant as the uncle of the new lord. ${ }^{4}$

Historical examples of the complex relations and multilayered roles played by house members are easy enough to come by. Far rarer are documents that plumb such relations with anything more than pious generalities or legal prescriptions. 
One such document, a memorandum for a young bride-to-be, was produced by a member of the Hōjō house of Odawara, a warrior known to us as Gen'an. A younger son of the same Sōzui mentioned above, he was born around 1505 and believed to have lived into the 1580s. (Gen'an was, thus, a witness to both the early expansion of the Hōjō under his father and to their rise to regional hegemony under his brother, nephew, and great-nephew. He may have lived long enough to see the house's demise in 1590.$)^{41}$

Gen'an was one of the more senior members of the Hōjo by 1562, when, it is believed, he composed his Memorandum (known as Hōjō Sōtetsu oboegaki) for a daughter of the third Hōjo head, Ujiyasu. ${ }^{42}$ The young woman, whom the text addresses without naming, was about to become the wife of the heir to the Kira, an old and prestigious but by then powerless house. Such marriage alliances were central to the expansion of Hōjō power, preparing and consolidating battlefield successes. The house head's daughters could expect to be married off to the heads of other houses; ${ }^{43}$ his noninheriting sons might be adopted by other houses as prospective heirs. ${ }^{44}$ In this case, the young Hōjō woman was reinforcing an existing alliance, for the father of her groom-to-be was married to one of Ujiyasu's many sisters..$^{45}$

The Memorandum is an unusual document in that it is addressed to a young woman rather than a son or an heir. (One scholar has argued that the bride was actually Gen'an's daughter, adopted by Ujiyasu to marry her off.) ${ }^{46}$ The Memoran$d u m$ is also unusually revelatory, for its instructions on interactions with retainers, with hereditary vassals, with elders, and with the lord's attendants remind us that the language seen elsewhere uniting kin and nonkin overlays a recognition that fine shades of status existed in the face of a rhetoric of unity. Reaching for different ways of signifying difference, the Memorandum ends up privileging status relative to house affiliation.

The text's twenty-four articles-some concise, some extensive-are not meant to cover all of the young woman's future duties or even most of them. Gen'an says nothing about a wife's role in managing the household or raising the next generation of Kira. Instead, he focuses on the etiquette of the lady's interactions with members of her natal and marital houses as well as with lords and retainers of different status. ${ }^{47}$ Typical of his concerns is the proper reception of elders from hereditary vassal houses (article 9); of elders from the future husband's natal house (article 10); of Kira house elders (article 11); and of close attendants of the Kira lord (article 12). ${ }^{48}$ In forging a marriage alliance with the Kira, a house with a reputation for expertise in matters of ceremony, the Hōjō leadership no doubt wished to draw on their in-laws' knowledge. At the same time, it is hard to escape the sense that such expertise put pressure on Gen'an to prove himself (and the bride-to-be) ceremonially competent.

Gen'an's Memorandum was intended as a primer for a bride, not a treatise on alliances and politics. Still, set against the backdrop of other sources, it reveals a tendency to refashion the sharp boundaries between houses into vague distinctions 
within a house. In the Hōjō-dominated Kantō region, the renewal of the alliance with the Kira reaffirmed a distinctly unequal partnership, one that exalted the Kira even as it threatened to extinguish the independence of the house. But not entirely: the Kira are absent from a 1559 register of all Hōjō kin and vassals, ${ }^{49}$ which indicates that the Hōjō had not established formal lord-follower relations with them and had not integrated them into their new military recruitment mechanism. No loyal service was expected from the Kira.

We do know that other alliances the Hōjō forged through marriage were meant to blur, if not erase, the boundaries between themselves and other houses, and, in this case too, Gen'an seems to presume considerable integration between in-laws. ${ }^{50}$ Several articles deal with the proper way of maintaining contacts with Gen'an's son Ujinobu and a nephew. ${ }^{11}$ Ujinobu would soon take over from Gen'an as the castellan in nearby Kozukue, and Gen'an repeatedly mentions him and other warriors associated with that stronghold.52 The young bride-to-be, the Memorandum implies, could expect to have plenty of dealings with Ujinobu in the future. For example, article 20 advises: "As for sending greetings to Ujinobu, in spring you must do so often. You should inquire with [your mother-in-law]." ${ }_{33}$ The bride would remain in close contact with her Hōjō relatives, while seeking-and obtaining, it is assumed-permission and guidance from members of her new family.

If marriage alliances symbolically united two houses, the Memorandum construes the union as literal: to Gen'an and other Hōjō, the Kira were now family. We see this when Gen'an instructs his great-niece on the differences and similarities to be observed in treating members of her birth family and in-laws. Article 1, on how to address the Kira lord, also dwells on how to address the Hōjō lords. The same title is used for both; a place-name is all that clarifies which lordship is which. ${ }^{54}$ Article 4, almost banal in offering instruction on the proper etiquette for interactions with Lord Kira before and after the wedding (use a go-between before the wedding but not afterward), reflects the shortening distance between the two houses if not their transformation into a single house. ${ }^{55}$

To be sure, in a primer on etiquette, distinctions remain all important. Yet the operative variable throughout is not kinship or membership in one house or the other. In sorting out the young bride's future interactions, Gen'an reveals to us one way past the ever-present tension between the ideal of inclusiveness and the reality of differences: what must organize interactions between house members was not the degree of kinship but rather each member's status. In article 16, Gen'an explains that the treatment of messengers should reflect the differences of status between the men who sent them: "[Reception of] a messenger conveying greetings from any among your relatives, such as Lord Ujiteru or Ujinobu, and of a messenger from [Lord Kira] should be slightly different. You should consult with [your mother-in-law] and make preparations." ${ }^{56}$ How they should differ is not specified; messengers from relatives were presumably to be treated with a little less ceremony than a messenger sent by Lord Kira. Yet significant here is that junior kin like 
Ujinobu and Ujiteru are set side by side with the head of the Kira house, separated primarily (and only slightly) by degrees of deference. Indeed, status rather than kinship is the determining factor, as shown in article 15: "You will be receiving greetings from the two [Hōjō] lords of Odawara [Ujiyasu and his heir, Ujimasa]. You must convey them [to Lord Kira], giving their messenger the reception you would an elder. Even if the messenger is [only] a close attendant, if he is a messenger from the lords, the reception must be the same. This is because the Lord [of Odawara] is currently [Kantō] Deputy. As for his messenger, failure to make every effort will not do." ${ }^{57}$

That both the Hōjō and the Kira were to be counted as family is no doubt a function of the Memorandum's first order of business: to help a young woman move from one house to another and negotiate relations with both. But repeated discussion of nonkin housemen complicates matters. Whose housemen? we must ask in such a situation. Were they Kira housemen or Hōjō housemen or neitherretainers attached to the bride-to-be? If status-based treatment of members of the Kira and Hōjō overshadows individual house loyalties (thereby affirming a new, higher loyalty to the hegemonic power, the Hōjō), the ambiguity surrounding the roles and affiliations of nonkin housemen underscores the difficulty of maintaining the view of houses as coherent and exclusive organizations. For these "housemen without a house," no less than for their social betters, the status they derived by proximity to the bride mattered more than affiliation with one or the other side of the marriage alliance. Men who had once been Hōjō affiliates were now expected to render service to the new bride; she, in turn, should treat those Hōjo followers who called on her as the new lady of the Kira house as if they were elder retainers, following their counsel on how to navigate relationships in her new household. (articles 18 and 19)..$^{58}$

These recommendations make clear that the ambiguous position was not women's alone. Three of the warriors mentioned in articles 18 and 19-Shimizu, Kasahara, and Takahashi-were members of the Izu band (one of the units of the Hōjō military machine used to mobilize supporters), which was under Gen'an's command. Kasahara, in particular, is listed first among its members in the 1559 register of Hōjō vassals. That Gen'an should single out him and Shimizu and mark them for special deference is not surprising. ${ }^{59}$ But Takahashi Gōzaemon's circumstances may have been different. An old Hōjō vassal (and a grandson of Sōzui on his mother's side), he was well versed in matters of etiquette and continued to serve the bride as she settled down in the Kira house. According to historian Tabata Yasuko, brides who left their natal families were typically accompanied by retainers of their own. As a result, high-level marriages had a direct impact on lowerlevel warrior families, for whom negotiating new, complex loyalties became a form of service toward the bride's father. ${ }^{60}$ Takahashi and a fourth warrior, Mizushi (the latter repeatedly cited as a messenger), seem to have served the bride-to-be in such a capacity, and recurring references to them underscore the text's expectation of 
assiduous interaction between the bride-to-be and members of her natal family.

The precepts' attention to the fine and not-so-fine shades of status and function helps make sense of the internal organization of a house. The text's mixing of Kira and Hōjō even while fastidiously minding status differences within both is suggestive of where the real distinctions were meant to be. Any ie was by necessity a composite of many kinship groups, and one's position within it, the Memorandum says, depended on one's role in the organization and one's status. Status was often determined by office and title in the country at large, metrics that may appear to transcend the confines of the house, but Gen'an shows us that its value (as well as its attainment) was of primary importance within the house. If his Memorandum highlights distinctions between different sorts of members and followers, it also shares with other texts we have encountered a basic understanding of the house's composition: the ie was not about family-or perhaps, depending on our how we feel about "family," family wasn't solely about kin. Truly, if self-referentially, the ie was about the organization. The demands on men like Takahashi and Mizushion a permanent tour of duty in the retinue of a woman forever caught between two lineages - suggest the degree to which "loyal service" came to be rendered less and less as part of a contractual relationship and more and more as part of a commitment to an expansive (and expanding) conception of the house. In the name of the conflation between kin and nonkin, the investment expected of kin had come to be expected of housemen as well.

\section{IN CONCLUSION}

In the Tokugawa period, the demands of loyalty became more absolute. In the didactic texts authored by righteous warriors, as in the commercial publications meant less somberly for a wider public, the emphasis on duty and self-sacrifice became paramount, all but obscuring the contractual nature of service. This may have been due, in part and increasingly as the decades went by, to the nostalgia of warriors alienated from their calling by their new condition as underemployed urban administrators. Inactivity no doubt made for a certain idealization of the warring past, while peace lowered the stakes of loyalty and disloyalty considerably.

But nostalgia's link to the transformation of loyalty is not causal. Rather, both were manifested as by-products of the development and dissemination, in the late sixteenth century, of ideas of public authority and assertions of the Toyotomi and Tokugawa regimes' exclusive right to judicial authority and the violence concomitant with its enforcement. The stripping by daimyo of their followers' right to selfredress, which was heightened at the end of the civil war by the removal of warriors from the countryside, also undermined much of the conceptual justification for negotiating loyalty and service. Little rhetorical space was left for any devotion short of absolute. One need only think of Yamamoto Tsunetomo's Hagakure, a text strident in its advocacy of the Nabeshima house's excellence and lapidary (and 
hyperbolic) in its declaration that the meaning of the Way of the Warrior was to be found in death - the ultimate, and definitive, act of loyal service. ${ }^{61}$

At the same time, the subjugation of daimyo to the shogunal regime in Edo created new problems: the house, for over a century the sole object of loyalty, now had to be understood as subsumed under a higher source of authority, for all daimyo houses were now themselves vassals of the Tokugawa house. Warlords were fitted into the Japan-wide framework of Tokugawa rule, so, even at the highest level, their houses could not stand alone as self-referential foci of service and attachment. In light of the realities of early modern rule, Yamamoto's scornful dismissal of other houses' martial traditions, as inferior and ultimately unnecessary to any Nabeshima warrior, rings hollow. Perhaps unsurprisingly, Yamamoto does not take a critical look at the real struggle behind the creation of the imperative of loyalty, for the uncompromising ideal he embraces and extols was the product of policies enacted by daimyo upon their followers. These policies were driven by, and beneficial to, the house as a politically autonomous unit and were rendered both widespread and less urgent by the new peace.

Although in pacifying the country the Tokugawa hegemons opted not to push for complete centralization, thus stepping back from the absolutist ideals of authority self-aggrandizingly promoted by daimyo during the civil war, pacification brought about a sort of upward transposition of claims to authority. The sphere of the public - and thus the legitimate-came to be preeminently associated with the rulers in Edo, leaving daimyo under suspicion of "private-ness." ${ }^{2}$ The newly problematic character of marriage alliances illustrates the limits imposed on warrior houses' claim to paramount positions. In the first of many versions of the "Laws Governing the Military Houses," the shogunate was blunt: "Marriage must not be contracted in private" (article 8). ${ }^{63}$ The encroachment on the familial (ie) sphere that was at the heart of the regime's monopolization of public and legitimate action helps us make sense of the paradoxical character of calls for absolute loyalty to one particular daimyo house-as seen in Yamamoto Tsunetomo's eighteenth-century rumination on the way of the warrior, Hagakure, but also, more flamboyantly, in the celebrated plays about the forty-seven rōnin's vendetta. Based on real events, the plays dramatized one of the central dilemmas of the age: the tension between, on the one hand, the shogunate's need to suppress feuding and uphold its monopoly on violence and, on the other, warriors' urge to display their prowess and rectitude through acts of absolute, even self-destructive abnegation. ${ }^{64}$

Yet the relocation to the dubious sphere of the private of nonsanctioned interactions between daimyo houses does not overshadow the fundamental continuities in the assumptions of both rulers and ruled. The new ideas of public, suprafamilial authority that undergirded both the Tokugawa's awesome accumulation of power and the daimyo's erosion of their followers' autonomy did not do away with the house as an institution. Marriages remained political affairs. Gen'an's lesson remained valid and potentially threatening. As his primer reminds us, if the 
warrior house was indeed a corporate group, a new marriage could be as good an occasion as any other to renegotiate its membership. If alliances were political affairs, so too were the contours of family.

\section{NOTES}

Epigraph: The Imagawa Precepts (Imagawa kabegaki; also known as the Imagawa Letter [Imagawa $j \overline{0}$ ]) is a letter of admonition said to have been written by the warrior Imagawa Ryōshun (1326-1420) to his brother and heir around the turn of the fifteenth century. Reprinted in Arima and Akiyama 2012, 46.

1. Tonomura 1990; Takahashi 1991; Takahashi 2004, 32-51.

2. Spafford 2013, 123-68.

3. Sakai 1999; Matsumoto 2001; Itō 2003.

4. Gunma-ken shi, vol. 7, p. 247 , doc. 1748.

5. Tochigi-ken shi, vol. 2, p. 129, doc. 49, and p. 107, doc. 71; the only difference between the two is the term "truly" (makoto ni), which appears only in the latter document.

6. Gunma-ken shi, vol. 7, p. 311, doc. 1864.

7. Tochigi-ken shi, vol. 3, p. 119, doc. 4. Other examples can be found, for instance, in long letters written by Ōta Dōkan in 1480 (Saitama-ken shi, vol. 5, p. 636, doc. 1003): "rendering loyal service together"; and by Uesugi Sadamasa in 1489 (in Saitama-ken shi, vol. 5, p. 656, doc. 1019): "striving in our loyal successes for the main house."

8. It could be argued that, to a certain extent, the ties that bound kin to a house were also negotiable, as younger sons could and did leave to establish new houses and take new surnames. While blood and kinship themselves were not easily denied, economically junior houses were distinct; absent shared entitlement to offices or landholding portfolios, political alignment could be precarious.

9. Saitama-ken shi, vol. 5 , p. 657 , doc. 1019.

10. Chikubashō, in Buke kakun, 67.

11. Asakura Sōteki waki, 4.

12. Asakura Sōteki waki, 2.

13. Asakura Sōteki waki, 1. The phrase recurs. See ibid., 2-3: "When it is important, they will be of great use." Also ibid., 3: "[If a lord is not beloved by his housemen], when it is important, it will be difficult [for them] to be of use by laying down their lives for him."

14. Saitama-ken shi, vol. 5, p. 635, doc. 1003 ("being in attendance"); Takeda Nobushige kakun, 124 ("serving their lord").

15. Hōjō Ujitsuna kakioki, in Buke kakun, 120.

16. I discuss this episode at length in Spafford 2013.

17. See Odawara-shū shoryō yakuchō.

18. Letter to Nagao Kagenobu, in Gunma-ken shi, vol. 7, p. 242, doc. 1730. For several other examples by Yoshimasa during the same campaign, see Tochigi-ken shi, vol. 4, pp. 315-26, docs. 15, 36, 37, 50, and 53-56.

19. Whether these laws simply record and regularize customary practices or expand daimyo prerogatives - and, if so, how and how much — is an important question that must be left for another study.

20. Imagawa kana mokuroku, 126-27. 
21. Chōsogabe-shi okitegaki, in Chūsei hōsei shiryō shū, vol. 3, p. 299.

22. Takeda Nobushige kakun, 126. Three Strategies (Ch. San lue) is a book of military strategy thought to have been produced at the end of the first century BCE. A virtually identical sentiment is expressed, without explicit reference to Chinese textual authority, in Ôtomo Yoshiaki okibumi (p. 204): "There must be no forgetfulness about the depth of one's service or the closeness of one's loyalty."

23. Saitama-ken shi, vol. 5, p. 655, doc. 1019.

24. Kawagoe $k i, 595$; the passage is from Lunyu I.11.

25. Legge 1966, 466-67.

26. Legge 1966, 470.

27. Knapp 1995; Knapp 2005, 8-9, 13-26; Brown 2007, 65-84; Goldin 2011, 31-38.

28. Kokusho sommokuroku (vol. 3, pp. 211-15) lists six extant titles dating back to the Warring States period, one of them, by Kiyohara Nobukata, in multiple copies bearing different dates; others must have been lost.

29. Katsumata 1976.

30. In some cases, space was shared in a literal sense, on the page: in the 1617 Kikkawashi hatto, lord-vassal and father-son relations are treated in consecutive articles (nos. 50-51 in Chüsei hōsei shiryō shū, vol. 3, pp. 317-18); in Ōtomo Yoshiaki okibumi, rules of service and rules for family sit next to each other (nos. 9-10, p. 204).

31. Chūsei hōsei shiryō shū, vol. 4, p. 151, doc. 199.

32. Imagawa kana mokuroku, 134. This is the last article of the "Sadame," which appears after the tsuikaho in the Kurokawa-bon version of the code.

33. Kōshū hatto no shidai, in Chūsei hōsei shiryō shū, vol. 3, p. 204.

34. Kuroda Josui kyōkun, in Buke kakun, 188.

35. Chūsei hōsei shiryō shū, vol. 4, p. 177, doc. 255.

36. See, for instance, one other entry in Otomo Yoshiaki okibumi, 204: "As for a crime by members of the same surname or relatives or lieutenants: if there is a judgment of the lawfulness or not, there must be no collaboration of members of the same surname or members of different surnames."

37. Hosokawa Masamoto sadamegaki, in Chūsei hōsei shiryō shū, vol. 4, p. 164, doc. 226.

38. Nakajō Fujisuke kishōmon, in Chūsei hōsei shiryō shū, vol. 4, pp. 197-98, doc. 298.

39. Quoted in Tabata 1998, 253.

40. Horton 2002, 31. See also the Imagawa kafu, 154.

41. Kuroda Motoki estimates that Gen'an was born around 1505 (about a decade later than generally stated); the last document he authored was dated 1582 (Kuroda 1989, 30-33).

42. Fujioka Tsuguhei's proposed date of composition remains accepted, as does his conclusion that the Hōjo woman about to marry the head of the Kira was one of Ujiyasu's daughters (Fujioka 1901, 1497-1506, 1521). See also Ogino 1975, 91-94.

43. Apart from the alliance with the Kira, several others among Ujiyasu's sisters and daughters found husbands among the great lords of the time: a sister married Ashikaga Haruuji of Koga; daughters married, among others, Haruujiss son, Yoshiuji, Imagawa Ujizane, and Takeda Katsuyori (see the figure in Kuroda 2012, 8).

44. Spafford 2014, 315-23. 
45. Kuroda 1997, 292-93. As for the groom-to-be, his situation was even more complicated. He was born into the Horikoshi house of Tōtōmi and his biological mother was yet another of Hōjō Ujiyasu’s sisters (Shimoyama 1975, 293).

46. Kuroda 1997, 297.

47. Although two articles (21, briefly; and 24, at great length) discuss the protocol of interactions with merchants and guild leaders, the majority of the primer focuses on kinsmen, in-laws, and different sorts of nonkin followers.

48. Hōjō Sōtetsu oboegaki, 302.

49. See Odawara-shū shoryō yakuchō. See also Ogino 1975, 66-78.

50. Spafford 2014.

51. For the sake of clarity in the translations that follow, I use the names Ujinobu and Ujiteru even when the original refers to Shinzaburō and Genzō.

52. Article 17 mentions several retainers of varying rank, from middling (Mizushi Mukunosuke, Konogi Zusho) to lower rank (Ōya, Nakata); Hōjō Sōtetsu oboegaki, 303. Of these, only Nakata is listed in Odawara-shū shoryō yakuchō (p. 204), as a member of the Kozukue band, though Mizushi is mentioned repeatedly as a messenger, which may imply that he, and possibly the others as well, were warriors from southern Musashi Province, assigned to serve the bride-to-be in the nearby Kira residence.

53. Hōjō Sōtetsu oboegaki, 304.

54. Hōjō Sōtetsu oboegaki, 301. The subtle variations are impossible to render faithfully in English: "You must refer to Lord Kira (Kira-dono) as 'On'yakata' [his lordship]. As for our [Hōjō] lord, it is good to refer to him as 'Odawara on'yakata.' Otherwise, you should refer to him either as 'Odawara-dono' or '[Odawara]-sama."

55. Hōjō Sōtetsu oboegaki, 301. "When you are to go to Lord Kira, someone of high status must act as a go-between. Conversely, after [you have been married], too much distance could be a bad thing as well."

56. Hōjō Sōtetsu oboegaki, 303.

57. Hōjō Sōtetsu oboegaki, 303-4.

58. Hōjō Sōtetsu oboegaki, 303-4. Art. 18: "When Shimizu [Yasuhide] and Kasahara [Mimasaka no kami] come to offer greetings, you should treat them as elders." Art. 19: "When the next day, employing Mizushi Mukunosuke as a messenger, you call for the elders who have come to welcome you, it is good to deliver word with great care. When wondering how to treat someone of great status, you should consult with [Takahashi] Gōzaemon. On whether you also give [a gift] to the messenger even after being offered greetings, you should trust the matter to Gōzaemon's opinion."

59. According to a contemporary chronicle, Odawara kyūki, Kasahara was among the socalled five elders (gokarōsh $\bar{u}$ ) and the castellan of Shimoda (quoted in Odawara-sh $\bar{u}$ shoryō yakuchō, p. 239, n. 122). Both Kasahara and Shimizu, like most members of the Izu band, mainly held lands in that province (Odawara-shū shoryō yakuchō, 122, 124, respectively), though Kasahara is also listed as having three holdings in Sagami, the Hōjō home province.

6o. Tabata 1994, 80-82.

61. Hagakure, 220.

62. See Toby 2001.

63. Buke shohatto, 454

64. For an extended discussion of literature on the theme of revenge, see David Atherton's article in this volume. 


\section{LIST OF REFERENCES}

Arima and Akiyama 2012

Arima Sukemasa and Akiyama Goan, eds. Bushidō kakunshū. 1906. Reprinted, Tokyo: Hakubunkan Shinsha, 2012.

Asakura Sōteki waki

Asakura Sōteki waki. In Zoku zoku gunsho ruijū, 4th ed., edited by Kokusho Kankōkai, vol. 10, pp. 1-12. Tokyo: Zoku Gunsho Ruijū Kanseikai, 1984.

Brown 2007

Brown, Miranda. The Politics of Mourning in Early China. Albany: State University of New York Press, 2007.

Buke kakun

Ozawa Tomio, ed. Buke kakun, ikun shūsei. Revised and expanded. Tokyo: Perikansha, 2003. Buke shohatto

Buke shohatto. In Kinsei buke shisō, edited by Ishii Shirō. Vol. 27 of Nihon shisō taikei, edited by Ienaga Saburō et al., 454-62. Tokyo: Iwanami Shoten, 1974.

Chūsei hōsei shiryō shū, vol. 3

Satō Shin'ichi, Ikeuchi Yoshisuke, and Momose Kesao, eds. Chūsei hōsei shiryō shū, vol.

3. Tokyo: Iwanami Shoten, 1965.

Chūsei hōsei shiryō shū, vol. 4

Satō Shin'ichi and Momose Kesao, eds. Chūsei hōsei shiryō shū, vol. 4. Tokyo: Iwanami Shoten, 1998.

Fujioka 1901

Fujioka Tsuguhei. "Hōjō Gen’an oboegaki no kō.” Shigaku zasshi 12:12 (1901): 1490-1522.

Goldin 2011

Goldin, Paul R. Confucianism. Berkeley: University of California Press, 2011.

Gunma-ken shi

Gunma-ken Shi Shiryō Hensan Iinkai, ed. Gunma-ken shi shiryōhen. 27 vols. Maebashishi: Gunma-ken, 1977-88.

Hagakure

Yamamoto Tsunetomo. Hagakure. Annotated by Saiki Kazuma and Okayama Taishi. In Nihon shisō taikei, vol. 26, Mikawa monogatari, Hagakure, edited by Saiki Kazuma, Okayama Taishi, and Sagara Tōru, 213-579. Tokyo: Iwanami Shoten, 1974.

Hōjō Sōtetsu oboegaki

Hōjō Sōtetsu oboegaki. In Sengoku ibun: Gohōjō-shi hen, edited by Sugiyama Hiroshi and Shimoyama Haruhisa, vol. 4, pp. 301-5. Tokyo: Tōkyōdō Shuppan, 1992.

Horton 2002

Horton, H. Mack. Song in an Age of Discord: The Journal of Sōchō and Poetic Life in Late Medieval Japan. Stanford, CA: Stanford University Press, 2002.

Imagawa kafu

Imagawa kafu. In Zoku gunsho ruijū, edited by Hanawa Hokinoichi, vol. 21, part 1, pp. 141-6o. Tokyo: Zoku Gunsho Ruijū Kanseikai, 1958.

Imagawa kana mokuroku

Imagawa kana mokuroku. In Chūsei hōsei shiryō shū, vol. 3, edited by Satō Shin'ichi, Ikeuchi Yoshisuke, and Momose Kesao, 115-34. Tokyo: Iwanami Shoten, 1965. 
Itō 2003

Itō Toshikazu. "Chūsei kōki shōenseiron no seika to kadai." Kokuritsu Rekishi Minzoku Hakubutsukan kenkyū hōkoku 104 (March 2003): 5-15.

Katsumata 1976

Katsumata Shizuo. "Sengoku-hō," in Iwanami Kōza Nihon rekishi, edited by Asao Naohiro et al., vol. 8, pp. 175-210. Tokyo: Iwanami Shoten, 1976.

Kawagoe ki

Kawagoe ki. In Shinkō gunsho ruijū, edited by Kawamata Keiichi, vol. 16, pp. 595-99. Tokyo: Naigai Shoseki, 1928-38.

Knapp 1995

Knapp, Keith N. “The Ru Reinterpretation of Xiao." Early China 20 (1995): 195-222.

Knapp 2005

Knapp, Keith N. Selfless Offspring: Filial Children and Social Order in Medieval China. Honolulu: University of Hawaici Press, 2005.

Kokusho sōmokuroku

Kokusho sōmokuroku. Revised and expanded. 8 vols. Tokyo: Iwanami Shoten, 1989-91.

Kuroda 1989

Kuroda Motoki. "Kuno Hōjō ni kansuru ichi kōsatsu: Hōjō (Gen’an) Sōtetsu to sono zokuen kankei o chūshin to shite." Miura kobunka 45 (June 1989): 30-46.

Kuroda 1997

Kuroda Motoki. Sengoku daimyō ryōgoku no shihai kōzō. Tokyo: Iwata Shoin, 1997.

Kuroda 2012

Kuroda Motoki. Koga kubō to Hōjō-shi. Tokyo: Iwata Shoin, 2012.

Legge 1966

Legge, James, trans. The Sacred Books of China: The Texts of Confucianism. Vol. 1, The Shü King: The Religious Portions of the Shih King, the Hsiāo King. Oxford: Clarendon Press, 1879. Reprinted, New Delhi: Motilal Banarsidass, 1966.

Matsumoto 2001

Matsumoto Kazuo. Tōgoku shugo no rekishiteki tokushitsu. Tokyo: Iwata Shoin, 2001.

Odawara-shū shoryō yakuchō

Sugiyama Hiroshi, ed. Odawara-shū shoryō yakuchō. Tokyo: Kondō Shuppansha, 1969.

Ogino 1975

Ogino Minahiko. "Musashi no Kira-shi ni tsuite no kenkyū: Gohōjō-shi no kōbō ni kanren shite." In Kira-shi no kenkyū, edited by Ogino Minahiko, 11-114. Tokyo: Meicho Shuppan, 1975.

Ōtomo Yoshiaki okibumi

Ōtomo Yoshiaki okibumi. In Chūsei hōsei shiryō shū, vol. 4, edited by Satō Shin'ichi and Momose Kesao, pp. 203-5, doc. 307. Tokyo: Iwanami Shoten, 1998.

Saitama-ken shi

Saitama-ken, ed. Shimpen Saitama-ken shi shiryōhen. 26 vols. Urawa: Saitama-ken, 1979-90.

Sakai 1999

Sakai Kimi. “Ōnin no ran to zaichi shakai.” In Kōza Nihon shōenshi, edited by Amino Yoshihiko, Ishii Susumu, Inagaki Yasuhiko, and Nagahara Keiji, vol. 4, Shōen no kaitai, 105-50. Tokyo: Yoshikawa Kōbunkan, 1999. 


\section{Satō 1989}

Satō Hironobu. Koga kubō Ashikaga-shi no kenkyū. Tokyo: Azekura Shobō, 1989.

Shimoyama 1975

Shimoyama Haruhisa. "Kira-shi kenkyū no seika to kadai." In Kira-shi no kenkyū, edited by Ogino Minahiko, 275-322. Tokyo: Meicho Shuppan, 1975.

Spafford 2013

Spafford, David. A Sense of Place: The Political Landscape in Late Medieval Japan. Cambridge, MA: Harvard University Asia Center, 2013.

Spafford 2014

Spafford, David. "What's in a Name? House Revival, Adoption, and the Bounds of Family in Late Medieval Japan. Harvard Journal of Asiatic Studies 47:2 (December 2014): 281-331.

Tabata 1994

Tabata Yasuko. Nihon chūsei joseishi ron. Tokyo: Kashiwa Shobō, 1994.

Tabata 1998

Tabata Yasuko. Nihon chūsei no shakai to josei. Tokyo: Yoshikawa Kōbunkan, 1998.

Takahashi 1991

Takahashi Hideki. "Chūseiteki 'ie' no seiritsu to chakushi." Shigaku zasshi 100:9 (September 1991): 62-82.

Takahashi 2004

Takahashi Hideki. Chūsei no ie to sei. Tokyo: Yamakawa Shuppansha, 2004.

Takeda Nobushige kakun

Takeda Nobushige kakun. In Buke kakun, ikun shūsei, edited by Ozawa Tomio. Revised and expanded, 124-45. Tokyo: Perikansha, 2003.

Tochigi-ken shi

Tochigi-ken Shi Hensan Iinkai, ed. Tochigi-ken shi shiryōhen. 25 vols. Utsunomiya: Tochigi-ken, 1973-8o.

Toby 2001

Toby, Ronald P. "Rescuing the Nation from History: The State of the State in Early Modern Japan." Monumenta Nipponica 56:2 (Summer 2001): 197-237.

Tonomura 1990

Tonomura, Hitomi. "Women and Inheritance in Japan's Early Warrior Society." Comparative Studies in Society and History 32:3 (July 1990): 592-623. 